\title{
Regulation of insulin gene transcription
}

\author{
D.Melloul, S. Marshak, E. Cerasi
}

Department of Endocrinology and Metabolism, Hadassah University Hospital, Jerusalem, Israel

\begin{abstract}
The mammalian insulin gene is exclusively expressed in the beta cells of the endocrine pancreas. Two decades of intensive physiological and biochemical studies have led to the identification of regulatory sequence motifs along the insulin promoter and to the isolation of transcription factors which interact to activate gene transcription. The majority of the islet-restricted (BETA2, PDX-1, RIP3b1-Act/C1) and ubiquitous (E2A, HEB) insulin-binding proteins have been characterized. Transcriptional regulation results not only from specific combinations of these activators through DNA-protein and protein-protein interactions, but also from their relative nuclear concentrations, generating a cooperativity and transcriptional synergism unique to the insulin gene. Their DNA
\end{abstract}

binding activity and their transactivating potency can be modified in response to nutrients (glucose, NEFA) or hormonal stimuli (insulin, leptin, glucagon like peptide-1, growth hormone, prolactin) through kinase-dependent signalling pathways (PI3-K, p38MAPK, PKA, CaMK) modulating their affinities for DNA and/or for each other. From the overview of the research presented, it is clear that much more study is required to fully comprehend the mechanisms involved in the regulated-expression of the insulin gene in the beta cell to prevent its impairment in diabetes. [Diabetologia (2002) 45: 309-326]

Keywords Insulin gene, beta cell, transcription factor, promoter, PDX-1, glucose, diabetes, NEFA, leptin, GLP-1.
Received: 23 May 2001 and in revised form: 15 November 2001

Corresponding author: D. Melloul, Department of Endocrinology and Metabolism, Hadassah University Hospital, P. O. Box 12000, 91120 Jerusalem, Israel, e-mail: danielle@md.huji.ac.il Abbreviations: PDX-1, Pancreatic duodenal homeobox-1; RIPE3, rat insulin promoter element 3; NRE, negative regulatory element; IEF-1, insulin enhancer factor-1; IPF-1, insulin promoter factor-1; STF-1, somatostatin transcription factor-1; IDX-1, islet duodenum homeobox-1; GSF, glucose sensitive factor; IUF-1, insulin upstream factor-1; Isl-1, islet-1; Cdx-3, caudal homeobox-3; Imx-1, LIM homeobox-1; HNF-1 $\alpha$, hepatocyte nuclear factor-1 $\alpha$; HMI(Y), high mobility group protein I (Y); bHLH, basic helix-loop-helix; USF, upstream stimulatory factor; GLUT 2, glucose transporter 2; IAPP, islet amyloid polypeptide; GK, Goto-Kakisaki; ZDF, Zucker diabetic fatty; GLP-1, glucagon like peptide-1; GH, growth hormone; PRL, prolactin; ILPR, insulin linked polymorphic region; VNTR, variable number of tandem repeats; HVR, hypervariable region; PI3-K, phosphatidylinositol 3-kinase; p38MAPK, p38 mitogen activated protein kinase; PKA, protein kinase A; CaMK, Ca/calmodulin-dependent protein kinase; PDE3B, phosphodiesterase 3B
Insulin, synthesized by the beta cells of pancreatic islets, is of major physiological importance in metabolic homeostasis. While mature insulin consists of two polypeptide chains joined by disulphide bridges, the gene encodes for a highly conserved single chain precursor, preproinsulin [1]. In most species preproinsulin exists as a single gene, whereas in the mouse and the rat two non-allelic insulin genes are present. The human insulin gene is located on the short arm of chromosome 11 (p15.5) [2], the rat insulin I and II genes are colocalized on chromosome 1 [3] and the mouse genes are positioned on two different chromosomes, insulin I on chromosome 19 [4] and insulin II on chromosome 7 [5]. In adult islets, the nonallelic genes appear to be coordinately expressed and regulated [6,7]. The rodent insulin II and the human genes contain three exons and two introns, whilst insulin I lacks the second intron. The organisation and structure of the insulin gene has been reviewed in detail [8]. Insulin is regulat- 

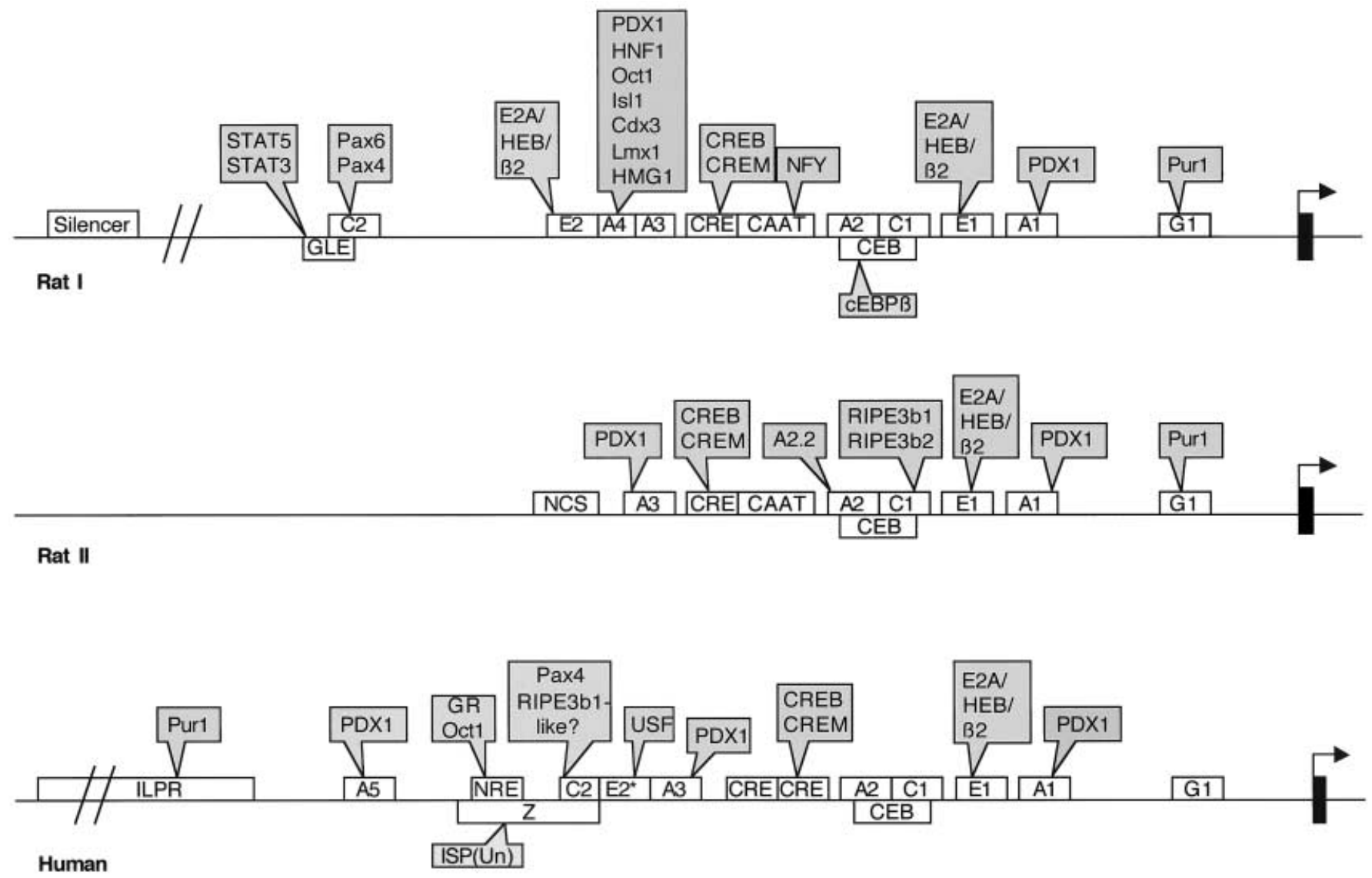

Fig. 1. Organization of human, rat I and rat II insulin enhancer and promoter regions. Cis-acting regulatory elements along the promoter regions of these genes are boxed. Proteins binding to these sequences are indicated above each box. A1-A5, E1-E2, C1-C2, and G1 elements are termed according to the nomenclature in [20]. E2* is an E2-like element; GR, glucocorticoid receptor; GLE, gamma-interferon-activated sequence (GAS)-like element; ISP(Un), islet-specific protein (unidentified); NRE, negative regulatory element; NCS, negative control sequences; $\mathrm{Z}, \mathrm{Z}$ minienhancer

ed at several levels, from gene transcription to insulin secretion. This review focuses on the transcriptional regulation of the insulin gene.

\section{Beta cell-specific expression of the insulin gene}

In the mouse embryo, insulin mRNA is first detected at stage E9 (20 somites) [9] in the foregut area from which the pancreas develops. In humans, insulin-positive cells are already present by the $8^{\text {th }}$ week of embryonic development [10].

In post-natal life, insulin gene expression is restricted to the beta cell. Most studies on the regulated expression of insulin used human and rat genes. Tissue specificity has been shown to be controlled by 5 , flanking regulatory regions of the gene [11]: a few hundred basepairs (bp) upstream of the transcriptional start site are sufficient to confer beta cell specific expression to an exogenous gene in transfected cells and transgenic mice. Thus, $660 \mathrm{bp}$ of the rat insulin II promoter region (RIP) was shown to direct the expression of simian virus $40 \mathrm{~T}$-antigen ( Tag) to beta cells [12]. The expressed viral oncogene induced tumour formation, permitting the establishment of valuable beta cell lines ( $\beta$-TCs). Moreover, correct initiation of insulin transcripts in mice together with cell-specific expression and physiological regulation of either the integrated human insulin gene [13, 14] or transgenes driven by the 5' flanking regions of insulin genes $[12,15,16]$ implied functional conservation of regulatory sequences between different species. Deletion and mutational analyses of various insulin promoter regions, conducted in transfected cell lines and in transgenic mice, led to the identification of cis-acting regulatory sequences necessary for specific-gene expression. Regulated insulin gene transcription relies on the interaction of sequence motifs in the promoter with a number of ubiquitous and islet specific transcription factors (Fig.1). These interactions determine the positive and negative regulation of insulin gene expression and its inducibility by physiological stimuli. The binding of proteins to regulatory elements has led to the identification and cloning of putative insulin transcription factors. The characterization of such factors (and their genes) contribut- 
ed to our current understanding not only of insulin gene expression, but also of endocrine pancreas development and of beta cell differentiation.

\section{Positive regulation}

Regulatory cis-acting elements and trans-acting factors involved in insulin gene transcription. Insulin genes share a number of conserved DNA motifs in their 5, flanking region [11], implying that they might be regulated by similar trans-acting factors. Amongst these, $\mathrm{E}, \mathrm{A}$ and $\mathrm{C} 1 / \mathrm{RIPE} 3 \mathrm{~b}$ elements seem to be major determinants of beta cell-specific expression of the insulin gene.

$E$ boxes (E1 and E2). Systematic mutagenesis of the rat insulin I promoter and transfection studies led to the identification of two closely related repeats, found to play an important role in beta cell-specific expression [17]. These elements, located between -104 and -112 (IEB1/E1) and between -233 and -241 (IEB2/E2), contain the core sequence belonging to the class of regulatory motifs designated $\mathrm{E}$ boxes, sharing the consensus sequence CANNTG. Similarly, mutagenesis of the rat insulin II 5' flanking region also showed that the conserved E1 motif (-100 to -91) is essential for selective expression of the gene $[18,19]$. As to the human insulin gene, a promoter fragment containing the E1 element (up to -170) showed low transcriptional activity in transfected fetal islet cells [20]. In contrast, a similar fragment significantly induced the expression of a reporter gene in transfected HIT-T15 cells [21]. Mutating the E1 box within the human insulin promoter would be necessary to resolve the conflict and evaluate its contribution to insulin gene expression.

E boxes bind proteins of the basic helix-loop-helix family (bHLH), which function as potent transcriptional activators of tissue-specific genes by forming heterodimers between ubiquitous (class A) and cellrestricted (class B) members. E1 binds the heterodimeric complex IEF1, which can include one of two alternatively spliced $E 2 A$ gene transcripts, the widely distributed bHLH proteins E12/E47 and $H E B$-encoded proteins (reviewed in [22]). These, in turn, interact with the cell type-restricted bHLH protein, BETA2/NeuroD, expressed in pancreatic and neuroendocrine cells, which is an important regulator of both insulin gene expression [23] and pancreatic development [24]. The pancreas of mutant Beta2 $2^{-/-}$ mice contained fewer beta cells, failed to develop mature islets, and the animals became diabetic [24]. Similarly, mutations affecting the DNA binding or the transactivation properties of Neuro D predispose to diabetes [25]. However, disruption of the E2A gene had no effect on beta cell phenotype [26], indicating redundancy between members of the A class bHLH family. While the E47/BETA2 complex controls both insulin and glucagon gene transcription, it was shown to bind to the glucagon promoter with much less affinity [27]. Of interest, overexpression of E47 inhibited only E box-mediated glucagon gene expression whereas it activated insulin gene transcription, suggesting that the E47/BETA2 ratio is important for regulated gene expression in islet cells. Thus, unique cooperative interactions allow the insulin $\mathrm{E}$ box enhancer to discriminate between different bHLH factors for achieving tissue-specific activation of the gene.

In contrast to the rat I gene, rat II and human insulin 5' flanking regions do not contain the conserved E2 box, but a related sequence in the human gene binds the HLH protein USF (upstream stimulatory factor) [28].

$A$ boxes (A1-A5). Additional prominent regulatory elements, containing AT rich sequences, are the A boxes (A1-A5) [11]. Except for A2 (GGAAAT), they all contain the core TAAT sequence which binds factors belonging to the homeodomain-containing protein family. Whereas the $\mathrm{A} 1$ and $\mathrm{A} 3$ boxes are the most conserved, mutated A3 had a more dramatic effect on transcription [29-31]. These promoter elements bind the pancreatic duodenal homeobox-1 (PDX-1) transcription factor, the mammalian homologue of the Xenopus laevis XlHbox8 [32], previously described as IPF-1 [33], STF-1 [34], IDX-1 [35], GSF [30,36], and IUF-1 [37]. PDX-1 functions both in the early commitment of the primitive gut to pancreatic fate and in the maturation of beta cells (reviewed in [38]). Mainly expressed in beta cells, PDX-1 is a major transactivator of the insulin gene $[29,30,33,36,39$, 40] and of islet-specific genes such as Glut 2 [41], glucokinase [42], IAPP [43] and somatostatin [34, 35]. Gene disruption experiments in mice showed that PDX-1 is imperative for the formation of the pancreas [44]. In experiments specifically carried out in beta cells using the Cre-loxP system, fewer insulin-positive cells and reduced insulin and Glut 2 expression were observed, leading to diabetes in these mice [45]. Furthermore, a patient with pancreatic agenesis had a mutated $p d x-1$ [46], whereas heterozygous mutants present MODY 4 [47]. Also, some cases of sporadic Type II (non-insulin-dependent) diabetes mellitus have been linked to $P d x-1$ mutations. However, these seem to be rare in the general diabetes population.

Although PDX-1 mostly stimulates islet-specific gene expression by binding as a monomer to its site, it was also shown to form a heterodimeric complex with PBX, the mammalian homologue of the drosophila extradenticle. This heterodimer bound the TAAT sequence of the somatostatin promoter but not that of the insulin promoter (A3 motif) [48]. PDX-1:PBX complexes have also been observed in exocrine cells, regulating elastase gene expression 
[49]. Thus, such preferences could form the basis for target-site selection in developing islet cells, and the transcriptional activity of the gene might thus be highly context dependent. Indeed, the PBX interaction domain in PDX-1 was shown in vivo to be dispensable for the generation of pancreatic endocrine and exocrine cells, but to be required for expansion of these cell populations during development. The heterodimer can therefore induce the expression of genes involved in islet neogenesis [50].

In the rat insulin I gene, the juxtaposed A3 and A4 boxes bind additional homeodomain-containing proteins; although not beta cell-specific, their expression is limited to few cell types. These include isl-1 [51], cdx-3, lmx-1 [52], HNF-1 $\alpha$ [53], HMGI(Y) [54].

According to the new nomenclature [11] the GGAAAT element (or GG1) was renamed A2 motif in view of its A rich sequence. It is highly sensitive to mutations as shown in the human insulin gene (GG1 and the related GG2) [55]. The contribution to overall insulin gene expression of the $30000 \mathrm{M}_{\mathrm{r}}$ protein binding this element has not been solved.

RIPE3 $b$. The rat insulin II enhancer, RIPE3 (-126 to -86), was shown to mediate beta cell-specific activity in transfection experiments and to confer correct temporal and tissue-specific expression to a transgene in vivo [56]. Positive control of RIPE3 is mediated by the RIPE3 $b$ and E1/ICE elements. RIPE3b is composed of two overlapping sequences, the A2 (-126 to -113) and the C-rich $\mathrm{C} 1$ element (-118 to -107). A2 was recently reported to bind three specific complexes; the one designated A2.2 was only detected in insulin-producing cell lines [57]. $\mathrm{C} 1$ binds two complexes, the beta cell-specific RIPE3b1-Activator/C1, and the more generally distributed RIPE3b2 [58]. RIPE3b1 was also composed of several proteins and its binding activity depended on tyrosine-phosphorylation. The loss of binding activity in phosphatase-treated extracts was prevented by tyrosine phosphatase inhibitors [59, 60]. In addition, the ability to specifically immunoprecipate RIPE3b1 binding protein with anti-phosphotyrosine antibody suggests that tyrosine kinase and/or phosphatase signalling could be involved in the regulated expression of the insulin gene by acting upon RIPE3b1 [60]. Cloning of the genes coding for the RIPE3b1 complex of proteins will be of major importance to elucidate its role in insulin gene expression.

Cyclic AMP response element (CRE). The second messenger cyclic AMP (cAMP) regulates the transcription of genes carrying cAMP response elements (CREs), mainly through binding the transcription factor CREB (CRE binding protein) to this motif, a member of the basic region leucine zipper (bZIP) family. This occurs via a mechanism involving activation of protein kinase A. Thus, phosphorylated CREB interacts with the basal transcriptional ma- chinery by binding the co-activator CREB binding protein (CBP) and activates transcription (reviewed in [61]). In the beta cell, glucose [62] and certain hormones including glucagon and the "incretin" GLP-1 $[63,64]$ increase intracellular cAMP. While cAMP, a potent enhancer of insulin secretion, stimulates gene transcription through CREs identified in the rat I [65] and II [18] insulin genes, it only has a modest effect on insulin mRNA levels [66-68].

In the human gene four sites were identified (two in the promoter region), all contributing additively to cAMP-inducibility [69]. The rat insulin I CRE confers basal activity, with relatively low cAMP-responsiveness. Although this correlates with poor binding of the cellular CREB to the insulin CRE, recombinant CREB showed higher binding affinity [70]. To clarify this paradox, additional CRE binding proteins acting as activators and repressors in islets and in beta cells have been identified [71-73].

The CRE modulator (CREM) gene generates a series of isoforms by alternative splicing which act as transcriptional activators and/or repressors [74]. CREM activators were shown to stimulate insulin transcription more efficiently than CREB, apparently by direct binding to components of the basal transcriptional machinery. CREM repressors, however, do not interact with these; they suppress transcription by competing with CREM activators or CREB on their binding sites [71]. Of interest, mRNA levels of a CREM repressor, which suppressed insulin transcription, were higher in islets of Goto-Kakisaki (GK) rats than in the control rats, suggesting a potential contribution to the decreased insulin gene transcription in this animal model of diabetes [72].

In the beta cell, activation of CREB also leads to the stimulated expression of the inducible cAMP early repressor (ICER). Plasma glucagon concentrations are sometimes increased in Type II diabetic patients; it is therefore of interest that glucagon induced the expression of ICER in beta cells, thus reducing insulin gene expression [73]. Whether such a mechanism contributes to decreased insulin production in Type II diabetes is not clear.

An alternative mechanism was suggested for rat insulin I where the CRE overlaps with a CAAT motif which binds the ubiquitous transcription factor NF-Y. This factor confers basal promoter activity and its binding attenuates the cAMP response [75].

Altogether, the fact that insulin CREs contain imperfect motifs, [TGACGTCA (consensus CRE); TGACGTCA (Rat I); TGttGTCc (Rat II); TGAtGTCc (Human)], and that differing sources of beta cells were used, could explain the disagreement regarding the mechanisms of cAMP-stimulation of the insulin gene.

C2 element. The $\mathrm{C} 2$ element, containing a direct CAGG repeat, was first described in the human insu- 
lin gene from -253 to -244 [76]. Although no equivalent motif was detected in the rat promoters, a related CACC sequence was found between -329 and -307 of the insulin I gene. This $\mathrm{C} 2$ element binds the transcription factors containing a paired domain and a homeodomain, PAX6 which acts as a transactivator [77] and PAX4 as a transcriptional repressor [78-80]. When coexpressed with PAX6 in beta cells, PAX4 dose-dependently suppressed the PAX6-induced transactivation of a reporter gene driven by a PAX recognition sequence [78]. This was not due to competition for a common binding site because repression was maintained even when the PAX DNA binding domain was replaced by that of the heterologous GAL4 protein [79].

An additional factor, binding to the human $\mathrm{C} 2$ and which exhibits RIPE3b1-like properties, was characterized as D0. Both the oxidizing agent diamide and the alkylating agent $\mathrm{N}$-ethylmaleimide abolished its binding, suggesting that a redox-dependent pathway involving a RIPE3b1-like factor could regulate insulin gene expression [76].

PAX6 and PAX4 are transcription factors that play an important role in pancreatic development (reviewed in [81]). Whilst PAX6 expression in islets is maintained until adulthood, PAX4 is only expressed in the early pancreas, being undetectable after birth. Hence, a direct effect on insulin gene transcription in adults can be excluded; rather, it could interact with other, as yet unidentified target genes involved in beta cell differentiation.

G1 or GAGA-box. Deletion analysis of the rat insulin I promoter led to the identification of the G/GAGA box as an important regulatory element [17, 31]. This is a purine-rich sequence located between -57 and $-40 \mathrm{bp}$. The ubiquitous zinc finger Pur-1/MAZ binds to rat insulin I and II genes and stimulates promoter activity [82]. However, G1 contribution to overall human promoter activity is doubtful because it failed to bind the Pur-1 transcription factor and its mutation did not affect transcription [20].

ILPR (VNTR, HVR). Insulin-linked polymorphic region $(I L P R)$, also referred to as variable number of tandem repeats $(V N T R)$ or hypervariable region $(H V R)$, is located at about $-360 \mathrm{bp}$ of the human gene. It has a variable number of repeats with the consensus sequence ACAGGGGT(G/C)(T/ C)GGGG. ILPR is highly polymorphic due to varying numbers of repeats and minor nucleotide variations within each repeat and has been classified into three main groups. Class I alleles with an average of 40 repeats are the most common, class II with an average 85 repeats are the least frequent, and class III has an average of 157 repeats. The unexpected finding that the IDDM2 locus of the susceptibility to Type I (insulin-dependent) diabetes mellitus was mapped to the $I L P R$ region has generated great interest as to its possible involvement in affecting insulin gene transcription. Whilst the short class I VNTR alleles have been reported to predispose to Type I diabetes (reviewed in [83]), class III alleles have been implicated in Type II diabetes susceptibility [84]. The correlation between these classes of ILPR alleles and insulin gene expression is not clear. Most of the evidence suggests that class III ILPR is associated with low levels of insulin mRNA [83, 85]. In contrast, using transfected beta cells, class I ILPR alleles were found to be transcriptionally less active than class III alleles [86]. Furthermore, variations within each repeat at IDDM2 also correlated with insulin mRNA levels in heterozygous individuals [87] as well as with transcriptional activity in transfection experiments [88].

This polymorphic G-rich minisatellite has the characteristic of forming unusual tetramer DNA structures in vitro, presumably through formation of G-quartets [89]. ILPR contains high-affinity binding sites for the transcription factor Pur-1, which binds the purine-rich G1 (GAGA) element in the insulin promoter [82]. Since for most but not all repeats activation by Pur-1 correlated with Pur-1 binding activity in vitro, other factors that recognize the G-quartet structure are likely to be involved in transcriptional regulation of the gene [88]. Indeed, single or double mutations that destabilise the loop-loop and loop-tetrad interactions dramatically affected insulin promoter activity [90].

Whilst the upstream $I L P R$, and more specifically the allelic variation within the repeat, seems to play a role in insulin gene expression, the relation to susceptibility to both types of diabetes is as yet difficult to assess.

Synergism. It has become evident that the insulin gene is regulated through the action of multiple activators, thereby providing a mechanism for combinatorial control. In fact, the arrangement of multiple activators in a single complex provides the capacity to integrate multiple regulatory inputs into a single output.

The most studied cooperative interactions are those between the proteins binding to the juxtaposed $\mathrm{E}$ and $\mathrm{A}$ elements. The rat insulin I promoter and more specifically its mini enhancer, previously named the Far-Flat region (FF), composed of an E2 motif and of the unique AT-rich A3/A4 sequence elements, has been the regulatory region of choice for this type of analysis. Homeodomain-containing factors binding to $\mathrm{A} 3 / \mathrm{A} 4$ elements functionally interact with the E2A-encoded proteins in transfected islet beta cells. The better studied PDX-1, acts synergistically with E47, a member of the bHLH family of transcription factors, to activate transcription [39, 40, 91]. Synergism requires the DNA binding and activation do- 
mains of both PDX-1 and bHLH proteins. It was further shown that the synergistic transactivation results not only from the coexpression of both E2A and PDX-1 but also of BETA2 involving its C-terminal activation domain and a region within the $\mathrm{N}$-terminus [92]. The role of PDX-1 was extended to recruitment of the transcription factors E47, BETA2/NeuroD and the high mobility group protein I, HMGI(Y), to form an activation complex on the FF mini enhancer [54]. The HMGI(Y) itself bound directly to the A3/ A4 elements to increase PDX-1 and bHLH transcriptional synergism [54]. Another A3/A4-binding homeoprotein, $\operatorname{lmx1.1}$, acted synergistically via its LIM domain with E47 to activate transcription [52].

Like the rat I mini enhancer, the RIPE3 enhancer of the rat II promoter contains an E1 (ICE) box which cooperates with the RIPE3b1 element [58, 93]. In this context, E47:BETA2 heterodimers require the presence of the beta cell-specific RIPE3b1Act/C1 complex to activate insulin gene transcription $[23,94]$. In the human gene as well, synergism was reported between $\mathrm{E} 1$ and $\mathrm{A} 1$ or $\mathrm{E} 1$ and $\mathrm{A} 2 \mathrm{C} 1$ [20].

The mechanisms responsible for efficient activation of the insulin promoter are not fully clarified. Conceivably, E2A, BETA2 and PDX-1 display cooperative binding not only through direct but also indirect protein-protein interactions, i.e. with the participation of coactivators. Although no beta cellspecific coactivator has yet been characterized, recently a new E2A-interacting protein, Bridge-1, which contains a PDZ-like domain has been identified [95]. It is highly expressed in islets where it functioned as a co-activator enhancing E12-mediated or E47-mediated transcription of the rat I gene. Inactivation of endogenous Bridge- 1 in INS-1 cells using antisense RNA led to reduced insulin I promoter activity.

The role of the ubiquitous coactivator p300 and its close homologue $\mathrm{CBP}$ has been investigated extensively. These are histone aceyltransferases, which stimulate transcription of specific genes by interacting either directly or through co-factors with a number of transcription factors and with the basal transcriptional machinery (reviewed in [96]). The adenoviral E1A oncoprotein, which binds a specific domain in the $\mathrm{p} 300 / \mathrm{CBP}$ proteins, was able to inhibit insulin promoter activity [97], probably by sequestering the coactivator. Cooperativity between p300 and bHLH proteins in activating E box-mediated transcription has been described [98]. Interactions of p300 with the bHLH members, E2A and BETA2 involved in the beta cell-specific IEF1 complex were shown to stimulate insulin gene transcription [99, 100]. The functional interacting domains are in $\mathrm{p} 300$ (aa 1945-2377) and BETA2 (aa 156-355). In E47 the activation domains spanning the aa sequences 1-99 and 325-432 were associated with the region aa $1-1257$ in p300.
Microinjection of $\mathrm{p} 300 / \mathrm{CBP}$ antibodies in muscle precursor cells blocked the transcriptional activity of myogenic bHLH and myotube formation [98]. It will therefore be important to assess the role of these coactivators in islet development and beta cell differentiation, especially in view of the ability of CBP, through its E1A binding domain, to interact with the activation domain of the key beta cell regulator, PDX-1 [101].

Thus, tissue-specific expression of insulin seems to depend not only on specific combinations but perhaps more importantly on the concentration of transcription factors, only some of which are restricted to the beta cell. Complete understanding of the molecular mechanisms underlying this expression will require detailed analysis of the interactions between the various transcription factors and coactivators.

\section{Negative regulation}

A silencer which decreases the activity of a heterologous promoter has been located between -4.0 and $-2.0 \mathrm{~kb}$ in the repetitive sequences of the rat I gene [102], whilst in the rat II gene a region between -217 and -197 was identified as the site of negative control [103]. In the human insulin gene, a negative regulatory element (NRE) was mapped between -280 and $-260[21,104]$. NRE was shown to contain overlapping putative sequences binding several nuclear proteins, among them the glucocorticoid receptor [105] and the ubiquitous factor Oct1 [104]. In fact, in HITT15 cells, dexamethasone inhibited the activity of an NRE-containing plasmid [105]. However, primary beta cells transfected with the human insulin promoter lacking this element showed reduced activity, indicating the presence of a positive rather than negative element in this region [20]. These observations suggest that NRE activity might be limited to transformed cells, again stressing the importance of using primary beta cells to confirm results obtained in cell lines.

Since cooperativity between transcription factors seems essential for strong expression of the insulin gene, proteins interfering with these positive interactions could provide the mechanism for down-regulating insulin expression.

E47-mediated inhibition of insulin gene expression. The inhibitory effect on transcription of Id proteins of the HLH family (lacking the basic DNA-binding domain) is a result of nonfunctional heterodimeric complex formation with lower DNA binding ability. Of interest, beta cells exposed to high glucose showed increased expression of $I d-1$ and $I d-3$ genes [106]. Their concomitant induction with that of insulin gene transcription and insulin secretion suggest that physiological concentrations of Ids do not inhibit in- 
sulin gene expression [106], but when overexpressed, Id protein was able to inhibit the rat II insulin promoter activity [107].

A stronger candidate as negative regulator of $\mathrm{E}$ box-mediated insulin gene expression is BETA3. Although a member of the B class of specific bHLHs and highly homologous to BETA2/NEUROD, it is not able to bind the insulin $\mathrm{E}$ box despite its intact basic region. BETA3 inhibited the binding of both E47 homodimer and E47/BETA2 heterodimer to DNA and consequently repressed E47/BETA2-mediated transactivation of the insulin enhancer [108].

Inhibition of insulin transcription by c-Jun was also shown to act through the E1 element; the repressed transcriptional activation implicated the basic leucine zipper region of c-Jun and the conserved activation domain $\mathrm{AD} 2$ of the $\mathrm{E} 2 \mathrm{~A}$ proteins, E12 and E47 [109].

Similarly, c/EBPß, a member of the leucine zipper family of transcription factors, specifically repressed insulin gene transcription in beta cells. In this case, the repression involved the direct interaction of the heptad leucine zipper of $\mathrm{c} / \mathrm{EBP} 3$ with the AD2 of E47, hence inhibiting the E47-mediated transactivation of the insulin enhancer [110]. Of interest, c/ EBPß is upregulated in beta cells chronically exposed to high glucose, and in the rat diabetes models of Zucker $(f a / f a)$ and $90 \%$ pancreatectomy, contributing to the downregulation of insulin expression [111].

The E box-mediated inhibition by either Id, BETA3, c-Jun or c/EBPß is probably due to their interference with E47 homo-dimer or hetero-dimer formation and consequently with the synergism involving A element-binding proteins.

\section{Nutrient and hormonal effects on insulin gene expression}

Glucose. Mammalian glucose homeostasis requires tight regulation of insulin production and release. Although the first evidence of glucose effect on insulin gene was reported about 30 years ago [112], we are only beginning to understand the complexity of the molecular mechanisms by which the sugar elicits this effect. The pioneering work of Permutt and Kipnis [113] revealed that glucose increases insulin synthesis by stimulating gene expression. It was suggested that glucose controls the steady-state insulin mRNA levels by enhancing both transcription and mRNA stability (reviewed in [114]).

The beta cell responds to the increase of blood glucose by increasing its rate of glucose metabolism, as well as stimulating insulin release and biosynthesis. The key elements of glucose sensing are the nonrate-limiting glucose transporter 2 [115] and the high $\mathrm{Km}$ hexokinase, the beta cell-specific glucokinase [116]. Glucose-induced insulin secretion in beta cells is initiated by closure of ATP-regulated potassium channels, causing plasma membrane depolarization with subsequent opening of the voltage-dependent calcium channels. The ensuing rise in cytosolic calcium triggers the exocytosis process. Several lines of evidence indicate that glucose metabolism is essential for beta cell-specific induced gene expression. This was evidenced by using metabolisable sugars such as mannose $[117,118]$ and glyceraldehyde [118], whereby the effect is blocked by mannuoheptulose, an inhibitor of glucokinase [117, 118]. Moreover, glucose metabolism is also necessary for the stimulatory effect on insulin promoter activity [117]. As for insulin secretion, glucose-induced transcriptional activity is mediated by the end-products of mitochondrial oxidation, as shown by co-transfecting beta cells with cDNAs encoding enzymes of glucose metabolism [119].

Inducible transcription seems to depend on the very same sequences in the promoter and/or enhancer region that control the cell-type specificity of the insulin gene. Thus, glucose-responsiveness is mediated by cis-acting elements within the 5 ' flanking region of the gene [29, 30, 36, 94, 120]. In beta cells it seems that a combination of several elements within the insulin promoter can produce the full glucose response and that more than one transcription factor is regulated by the hexose. The most studied elements in this context are A3, C1 and E1. Factors binding to these sites were suggested to be modulated by glucose and mutation of the elements led to impaired glucose-regulated transcription [20,29-31, 121]. Numerous studies have shown that extracellular glucose concentrations regulate the binding of PDX-1 and RIPE3b1Act/C1 to the $\mathrm{A} 3$ and $\mathrm{C} 1$ elements, respectively. However, little [31] or no increase [94] in the binding of the IEF1 complex to E1 has been observed. An additional glucose-responsive element in the human insulin gene (-292/-243, also called Z mini enhancer) was described using cultured primary fetal islet cells, and the sequence between -292 and -263 interacted with a yet unidentified islet-specific glucose-modulated complex [122].

As described previously, the RIPE3 region contains the E1/ICE and RIPE3b1/C1 elements. Whilst RIPE3b1-Act/C1 binding activity was selectively stimulated by high glucose concentrations, binding to E1/ICE and RIPE3a2 elements were not affected [94]. Additional metabolic effectors such as mannose and pyruvate were shown to modulate RIPE3b1Act/C1 in beta cells, suggesting that a common signal during glucose metabolism mediates both insulin transcription and secretion [121]. As mentioned earlier, tyrosine kinase/phosphatase was recently shown to influence RIPE3b1 binding to the insulin $\mathrm{C} 1$ element. Since phosphorylation seems to be required for the binding, it will be of great interest to assess whether RIPE3b1 activity in glucose-treated beta 
cells is regulated by this process. The proteins involved in the RIPE3b1-Act/C1 complex are being purified [59] and it is hoped that the gene encoding them will soon be isolated to determine its role in the cell-specific and nutrient-regulated expression of the insulin gene.

Of the factors associated with glucose-regulated expression of the insulin gene, the PDX-1 protein has been the most studied. The importance of the FF mini enhancer element of the rat I gene (around -200 to -250 ) in conferring glucose-responsiveness to a reporter gene was first shown in transfected fetal rat islets [120]. Using normal adult rat and human islets we have further mapped the glucose-sensitive element to the sequence containing the conserved A3 motif [36]. Furthermore, we identified an isletspecific glucose sensitive factor (GSF) whose DNA binding to the A3 motif is modulated by extracellular glucose concentrations [36]. The sequence of the purified protein was shown to correspond to PDX-1 [30], thus providing direct evidence for the involvement of this homeodomain protein in glucose-responsiveness. A point mutation in the A3 element in the human insulin promoter abolished the stimulatory effect of glucose in adult islets, supporting the suggestion that PDX-1 plays a major physiological role in glucose-regulated expression of the insulin gene $[29,30]$. Furthermore, expression of PDX-1 in NES2Y cells lacking this protein [123], as well as in islets of the Type I diabetes model Psammomys obesus, also devoid of the conserved form of PDX-1, restored their ability to regulate insulin mRNA levels in response to glucose [124]. Thus, in addition to its important roles in the development and differentiation of pancreatic islets and in beta cell-specific gene expression, this protein functions as an essential mediator of the glucose effect on insulin gene transcription in differentiated beta cells $[29,30,36,37]$.

The transcriptional mechanisms involved in this process are not fully understood; to that end, the mapping of the functional domains of PDX-1 is required. The activation domain of PDX-1 is located within the $\mathrm{N}$-terminus of the protein $[91,125,126]$ and the regions essential for its transactivation have been delineated [126, 127]. Of interest, the transactivating potency of PDX-1 is also modulated by glucose $[126,128]$ and the metabolisable hexose mannose, but not by 2-deoxy-glucose [128]. We found that the subdomains in the human PDX-1 protein of importance for glucose-mediated transactivation span the amino acid sequences $20-50$ and 97-120. Thus, glucose modulates the DNA binding and the transactivation activities of PDX-1 to fully regulate insulin gene transcription in differentiated beta cells.

The signalling pathways responsible for glucose induction of insulin gene transcription are under investigation. The finding that insulin gene transcription is inhibited by calcium channel blockers [120, 129,
130] and activated after beta cell membrane depolarization in HIT-T15 and islet cells [130], suggests that the stimulatory effect is in part mediated by increased intracellular calcium, analogous with the regulation of glucose-induced insulin secretion. However, this concept has been contested in beta cell lines [117, 131, 132], in islets [131], and the human beta cell line NES-PDX-1 which lacks voltage-gated calcium channel activity [123]. To date, while glucose metabolism is indisputably required for the transmission of the glucose stimulus for beta cell-specific gene expression, the exact nature of the intracellular signalling pathway has not been solved. The variability of the beta cell systems and testing conditions used hampers firm conclusions; nevertheless, the results indicate that the insulin secretion and transcription pathways differ in some aspects and that these two processes can occur independently.

The rapidity by which PDX-1 alters its binding implies a post-translational modification rather than de novo protein synthesis. A variety of signalling pathways are activated by beta cell glucose metabolism, several of which are presumed to regulate insulin gene transcription. Cyclic AMP is one, as it has been shown to augment insulin mRNA levels [67, 120]. However forskolin, which raises intracellular cAMP concentrations, had no effect on PDX-1 binding apart from the glucose concentration [37]. Another mechanism proposed to control gene expression in response to extracellular stimuli is the activation of specific protein kinases and/or phosphatases that uniquely modify the phosphorylation status of sequence-specific transcription factors. In beta cells, several signalling pathways have been described which involve kinase activation including protein kinase A (PKA), protein kinase $\mathrm{C}(\mathrm{PKC})$, members of the calcium calmodulin-dependent kinases (CaMK) and of the mitogen activated protein kinases (MAPK) [133].

It was reported that in human islets, or in MIN6 beta cells, a specific inhibitor of stress-activated p38MAPK, SB103580, inhibits glucose-stimulated binding of PDX-1 to DNA as well as PDX-1-dependent gene transcription [37, 134]. Moreover, overexpression of $\mathrm{p} 38$ kinase mimicked the glucose effect on PDX-1 binding and stimulated transcription of the human insulin promoter. Furthermore, the transfer of islets from low to high glucose concentrations was associated with the translocation and the rapid conversion of a cytoplasmic $31000 \mathrm{M}_{\mathrm{r}} \mathrm{PDX}-1$ protein to a nuclear $46000 \mathrm{M}_{\mathrm{r}}$ form [135]. Both findings have been challenged. Using the same specific inhibitor as well as overexpressing the p38 MAPK/SAPK2 or the upstream kinase MKK6, no effect on insulin promoter activity was observed [136]. However, overexpression of a constitutively active form of phosphatidylinositol 3-kinase (PI3-K) mimicked the glucose effect on the promoter activity, which was blocked by LY294002, a PI3-K inhibitor, as well as by the expres- 
sion of a dominant negative form of the p 85 subunit. No change in the apparent molecular weight of PDX-1 was observed in extracts of cells incubated at low or high glucose concentrations [136]. Most importantly, the endogenous PDX-1 seems to reside predominantly within the nucleoplasm in cells maintained in either glucose concentration [136] with only a small proportion residing in the cytoplasm at low glucose.

Mitogen-activated protein kinases play a major role in the regulation of a number of transcription factors in response to extracellular stimuli. However, in glucose-induced insulin gene transcription the situation is far from clear. MAPKs are believed by some authors to participate in the regulation of insulin secretion (reviewed in [133]). It was suggested that in beta cells p38MAPK/SAPK2 is activated via the PI3-kinase pathway [134]. It is conceivable that p38MAPK/SAPK2 activity is sensitive to the slight osmotic stress produced by high glucose concentrations similarly to that obtained with arsenite, which triggered the activation of MAPKAP kinase-2, a downstream target of p38MAPK, in a PI3-kinase independent manner.

In conclusion, PI3-kinase could be a central regulator of PDX-1 and of glucose-induced insulin gene transcription. However, it is essential to elucidate the link between glucose metabolism and kinase activation. This process has been suggested in part to be the result of a feedforward mechanism involving the binding of the secreted insulin to its receptor on the beta cell surface (Fig. 2). The degree of complexity of the signalling pathways that link glucose to insulin transcription is such that it will take some time to elucidate all the mechanisms involved. It is therefore of importance to map the specific phosphorylation sites not only of PDX-1 but of other transcription factors modified by change in extracellular glucose concentration and consequently to study the kinases potentially involved in glucose-regulated insulin gene expression.

Effects of chronic exposure to high glucose. It is controversial as to whether in Type II diabetes insulin biosynthesis is compromised to the same extent as is insulin secretion. While the maximal insulin responsiveness to stimuli is markedly reduced, upon autopsy of Type II diabetic subjects most islets showed only limited reduction in proinsulin mRNA [137]. Chronic blood glucose increase in humans and in experimental animals reduces insulin secretion. This has led to the concept of "glucose toxicity", whose effect on insulin gene expression has attracted the attention of several laboratories. In HIT-T15 beta cells cultured at high glucose concentrations, a reduced binding of both PDX-1 and RIPE3b1-Act/C1 to their sites was reported [138]. However, only RIPE3b1-Act/C1 binding was affected in BTC6 cells cultured in high glucose [139]. This indicates that the role of insulin transcription factors in overall insulin gene expression varies with the specific beta cell line investigated. We found that glucose-induced insulin release and islet insulin content were markedly reduced in cultured human islets chronically exposed to high glucose concentrations. This was accompanied by a major reduction in insulin mRNA levels and in human insulin promoter transcriptional activity [140]. The loss of promoter activity was associated with marked reduction in PDX-1 binding to the human insulin A3 element. RIPE3b1-Act/C1 binding was also reduced, albeit to a much lesser extent. In contrast, IEF1 binding to the E1 element was not affected. The decline in PDX-1 binding was largely associated with a reduction in $p d x-1$ mRNA; correction of the "hyperglycaemic milieu" reversed these effects to a certain degree [140]. Decreased insulin gene transcription was also associated with upregulation of the transcription factor c/EBP-ß in beta cells exposed to high glucose concentrations [110], as well as in the Zucker fatty $(f a / f a)$ rat and in $90 \%$ pancreatectomized rats [111].

Although the molecular mechanisms that lead to glucose toxicity are not known, glycation and generation of reactive oxygen species have been proposed as mediators [141]. The decreased $p d x-1$ mRNA could result from deleterious effects of supraphysiological glucose concentrations on the transcription factors controlling its expression. It is therefore important to elucidate the regulatory elements and transcription factors involved in the controlled expression of the $p d x-1$ gene in beta cells, and as such, we have recently shown that $p d x-1$ gene transcription is controlled in part by the PDX-1 protein itself [142]. Additional factors regulating $p d x-1$ gene transcription have been identified [142-145] and the damaging effect of high glucose on their activity needs to be addressed.

An additional correlation between $p d x-1$ and diabetes came from genetic studies of MODY families where few mutations have been described in the gene, one with a frameshift mutation showing a dominant negative effect in vitro [146]. Three additional missense mutations were identified in subjects with Type II diabetes; these showed variable reduction to the A3 site of the human insulin gene, and decreased promoter activity [147]. Since they were not highly penetrant MODY mutations, it was postulated that they might predispose to Type II diabetes, with phenotype depending on the severity of the mutation.

Ultimately, to determine the molecular mechanisms responsible for the deleterious effects of high glucose concentrations on insulin gene transcription, further studies in primary islet cells will be necessary. Whatever the mechanisms involved, the experimental work cited here strongly suggests that uncontrolled hyperglycaemia can lead to reduced insulin gene expression, loss of beta cell insulin reserves, 
and therefore, aggravation of the insulin deficiency and of the metabolic dysfunction.

Insulin. Evidence for a negative feedback of insulin secretion $[148,149]$ and gene expression [150] by insulin has been reported. More recent studies indicate that insulin exerts stimulatory effects on insulin production (reviewed in [151]). General disruption of the insulin receptor substrate 2 (IRS-2) in mice caused important beta cell defects [152]. A functional role of the insulin receptor in insulin-producing cells was directly demonstrated by beta cell-targeted inactivation of the receptor in mice. This resulted in a selective loss of first-phase secretion in response to glucose and a progressive impairment of glucose tolerance [153] which are typical characteristics of Type II diabetes. Insulin might also be acting on other beta cell-specific gene products such as GLUT 2 and glucokinase and a defect in insulin signalling pathway could lead to impaired glucose sensing. This is supported by the recent finding that insulin regulates glucokinase gene transcription in beta cells [154].

The mechanism by which insulin exerts stimulatory effects on its own transcription was suggested to involve the IRS2/phosphatidylinositol 3-kinase (PI3$\mathrm{K})$ and p70 S6 kinase, as well as the calcium calmodulin kinase pathways, but not the stress-activated protein SAPK2 [130]. Stimulation of insulin gene expression by insulin receptor signalling has been reported to be glucose dependent, also involving PI3-K in this process [155]. While data from mutational analysis of the rat insulin I promoter [130] indicated that the A3/4 elements are involved in the insulin effect, the $\mathrm{E}$ boxes could be the main mediators in islet and HIT-15T cells. However, the effect of insulin on the homeodomains binding to A3/4 (including PDX-1) and on IEF binding to the E elements needs to be tested. Similar experiments were conducted using the human insulin promoter where it was shown that insulin stimulates both the DNAbinding activity of PDX-1 to its cognate A3 sequence and the insulin promoter activity in MIN6 cells [156]. It was further shown that these effects are mediated not only by PI3-K but also by SAPK2. Here again discrepancies can originate from the use of insulin promoters and beta cells from different origins. Taken together, however, the data indicates that glucose and insulin (involving PI3-K) activate insulin gene transcription and that the effects can be additive in the beta cell, as suggested recently [157]. Defects in insulin signalling in the beta cell could contribute to the pathology of Type II diabetes, thus forming a link between peripheral insulin resistance and deficient beta cell function. Nevertheless, it is our impression that, in quantitative terms, glucose is the dominating regulator of insulin gene expression. Further studies involving several sources of beta cells and various diabetes models will be needed to evaluate the exact role of the insulin effect on insulin biosynthesis.

Non-esterified fatty acids (NEFA). Fatty acids represent important physiological fuels for beta cells, where they stimulate glucose-induced insulin secretion in the short-term, but after prolonged exposure exert inhibitory effects (reviewed in [158]). Although differences in fatty acid effects on insulin gene transcription have been reported, high concentrations of the saturated fatty acid palmitate represses insulin gene expression in the presence of high glucose [159-162]. This inhibition was shown on insulin transcription and mRNA stability [160]. Whilst decreased insulin transcription was shown to be associated with reduced activity of the rat I [160] or the human [159] insulin promoters, the mechanism underlying this effect is controversial. A study [161] showed dose-dependent decrease in $p d x-1$ mRNA and protein in islets exposed to palmitate, which correlated with impaired expression of islet-specific genes such as insulin, Glut 2, glucokinase, and somatostatin, all regulated by PDX-1. In contrast, other investigators [160] failed to observe any effect of palmitate on DNA binding of PDX-1. This and other discrepancies, such as the adverse effects of the monosaturated fatty acid oleate [160], could be explained in part by differences in glucose concentration as well as in the origin of the beta cells used. The inhibitory effect of palmitic acid on insulin gene expression does not seem to require mitochondrial oxidation, since it was reproduced by the non-oxidizable fatty acid analogue bromopalmitate [160,162]. It was also suggested to be associated with glucose-dependent increase in esterification of fatty acids [162]. This resembles the situation described in Zucker diabetic fatty (ZDF) rats, carrying a defective leptin receptor, which have increased esterification and high intracellular triglyceride concentrations, believed to contribute to beta cell dysfunction, apoptosis, and diabetes.

Glucagon-like peptide-1 (GLP-1). GLP-1, a physiological incretin hormone, is derived from post-translational processing of proglucagon and secreted from enteroendocrine L-cells of the intestine. GLP-1 binds to a $G$ protein-coupled receptor on beta cells to stimulate glucose-induced insulin secretion, biosynthesis and cell growth. These stimulatory effects on beta cell functions have partly been attributed to increased intracellular cAMP concentrations with concomitant activation of PKA (reviewed in [163]).

GLP-1 increases the preproinsulin mRNA by stimulating insulin gene transcription [63, 164, 165] and by increasing mRNA stability [165]. The effect of GLP-1 on insulin gene expression seems to be mainly mediated via the CRE in the promoter region $[63,164]$. Indeed, mutated CRE introduced into the rat insulin I promoter attenuated the GLP-1 effect 
and a dominant negative form of CREB inhibited the action of GLP-1 on the wild type promoter [64]. Furthermore, in this study there was evidence that activation of CRE occurs independent of the cAMP-mediated activation of PKA [64]. The nature of such an alternative pathway remains to be determined. It was recently suggested that an additional effect of GLP-1 on rat I promoter activity is mediated by the glucose-sensitive sequences (E2-A3/A4) [166]. This is likely to be caused in part by the activation of $p d x$ 1 expression (via its own CRE) by GLP-1 [64, 66, 167] resulting in increased PDX-1. GLP-1 also stimulated the PDX-1 transactivating domain potency in the presence of low and high glucose [166]. The mechanism, as well as the PDX-1 subdomains involved in this process, have yet to be determined. It would be of interest to test whether this effect is mediated by phosphatidyl 3-kinase, shown to be activated by GLP-1 [66] and to be important for glucose regulation of the insulin gene [136].

Leptin exhibits opposing actions to GLP-1 in beta cells, suppressing insulin secretion and gene expression. It is interesting to note that responsiveness of the rat I promoter to both factors was impaired when the sequence from -410 to -307 was deleted. This region contains the STAT5 recognition site, shown to be involved in growth hormone responsiveness [168]. How these three signalling pathways converge on this sequence to modulate insulin gene expression is intriguing.

Leptin. The $o b$ gene, its product leptin and its cell surface receptor (OB-R) are important factors in the regulation of food intake and energy balance. Although rare in mice and humans, leptin deficiency causes severe obesity suggesting that the hormone plays a similar role in both species. However, the increased leptin concentrations observed in other obese rodents and humans point towards leptin resistance rather than leptin deficiency as contributor to obesity. Obesity is associated with several pathological conditions including Type II diabetes, thought to result from the inability of the beta cell to increase insulin production in compensation for insulin resistance [169]. OB-R mRNA was detected in great abundance in islets, mainly in beta and $\delta$-cells but not $\alpha$-cells. Thus, the beta cell is a target for leptin action. Apart from the variability depending on the experimental system used, it appears that leptin inhibits insulin secretion in the presence of high glucose concentrations, mainly when potentiators that increase intracellular cAMP are added [169]. Leptin causes dependent the activation of the PI3-K-cyclic nucleotide phosphodiesterase 3B (PDE3B), with subsequent reduction of cAMP concentrations; consequently, it exhibits opposing actions to GLP-1 in beta cells [170].

Leptin has been shown to repress insulin expression in $o b / o b$ islets as well as in beta cell lines [171].
In contrast, other studies showed that leptin had a stimulatory [172] or no [173] effect on insulin biosynthesis. The leptin and growth hormone receptors-associated janus kinase (JAK) converts the latent monomeric STAT molecule (member of the signal transducers and activators of transcription family) to an active dimeric form through tyrosine phosphorylation. The dimers bind to specific DNA response elements and induce transcription. The leptin-sensitive inhibitory sequences, located between -410 and -307 of the insulin gene, bind multiple protein complexes activated in extracts from $o b / o b$ islets treated with leptin. One of these includes STAT5b and is formed on a consensus STAT binding site in the rat insulin I promoter [171]. Although STAT5 $b$ has been shown to activate the rat I promoter through the same STAT5 motif in response to growth hormone, it is likely that leptin mediates the repression through multiple additional complexes detected in this region. Leptin activated the STAT3 pathway by increasing the phosphorylation of STAT3 and MAP Kinase pathway in RINm5F cells [174]. Thus, the importance of JAK/STAT and possibly MAP Kinase signalling pathways in the regulation of insulin gene expression by leptin is not clear. Nevertheless, if the inhibitory effect of leptin on insulin gene expression is verified in human islets, it could point towards one additional mechanism that would favour the development of Type II diabetes in obese individuals.

Growth hormone $(G H)$ and prolactin (PRL). Growth hormone (GH), prolactin (PRL) and placenta lactogen (PL) are primary regulators of pancreatic beta cell proliferation. In addition, these hormones stimulate insulin production, in part by stimulating insulin gene transcription ([168, and reviewed in 175]). Expression of GH and PRL receptors was found in rat islets and various beta cell lines. Upon binding, these hormones activate the JAK/STAT pathway resulting in the nuclear translocation of STAT proteins which then bind $\gamma$-interferon-activated sequence (GAS)like elements, thus activating transcription of target genes [176]. In fact, a STAT5 binding element in the rat insulin I gene was identified in the sequence between -330 and -322 and shown to confer $\mathrm{GH}$ and PRL responsiveness to a heterologous promoter [168]. Furthermore, GH and PRL activated DNA binding of STAT-5 a and STAT-5 $b$ in beta cells $[168$, 177]; this correlates with the GH-induced and PRLinduced nuclear translocation of STAT-5a and STAT-5b in these cells [178]. Activation of STAT proteins, which are able to form homo dimeric and heterodimeric DNA binding complexes, could be an important determinant of gene-specific effects in beta cells. Such induction of insulin gene expression seems to require the stimulation of calcium uptake, since the calcium channel blocker verapamil prevented GH-induced insulin gene transcription in beta 


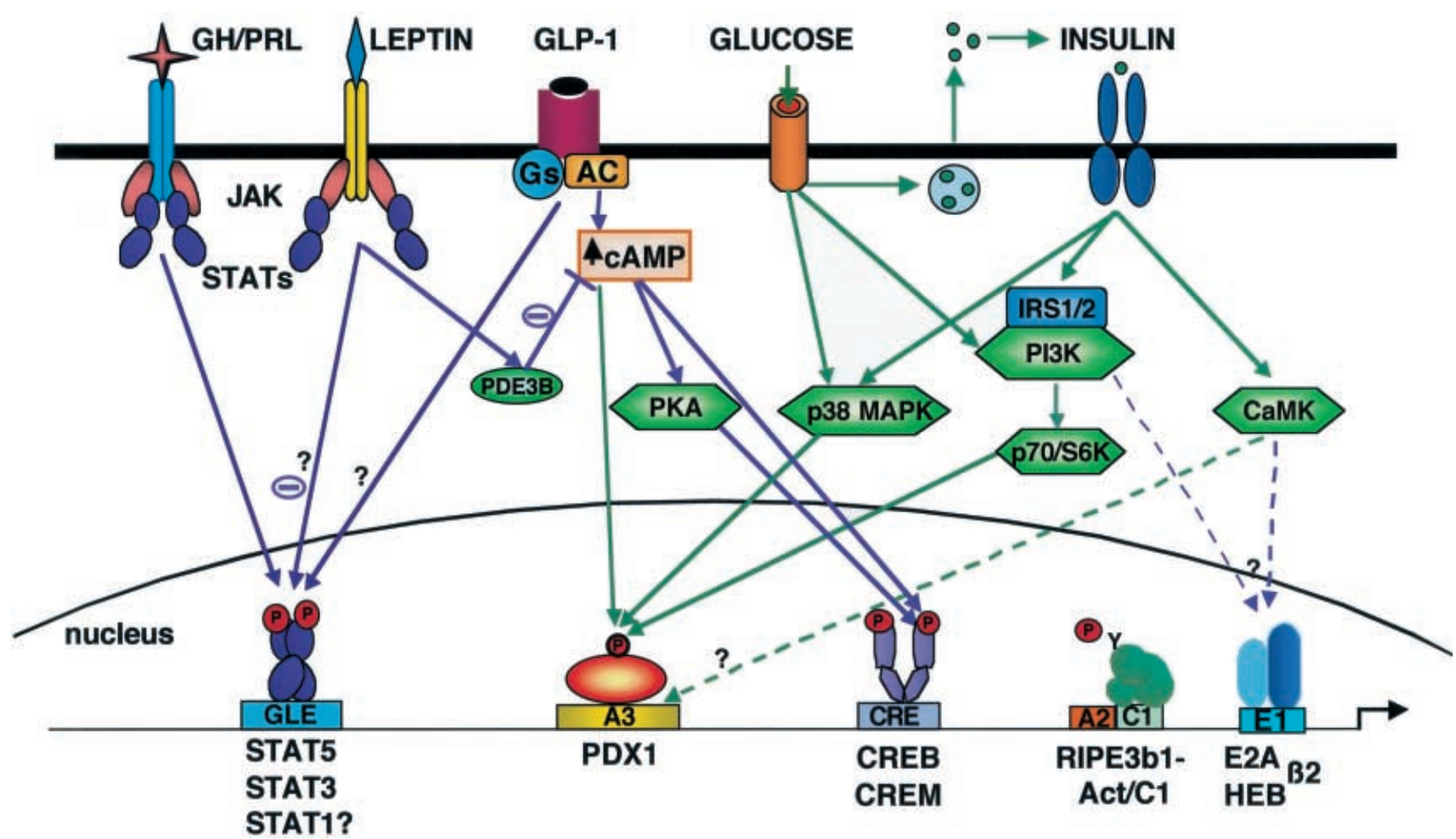

Fig. 2. Scheme illustrating possible signal transduction pathways and target transcription factors which regulate insulin gene transcription. The names of binding proteins are indicated underneath their corresponding sites. Green arrows converge to the PDX-1 protein. GH, growth hormone; PRL, prolactin; GLP1, Glucagon-like peptide 1; AC, adenylate cyclase; JAK, Janus tyrosine kinase; PKA, protein kinase A; PI3-K, phophatidylinositol 3-kinase; MAPK, mitogen activated pro-

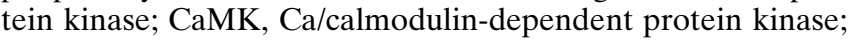
IRS, insulin receptor substrate; PDE3B, phosphodiesterase 3B

cells [179]. Investigating the role of glucose in PRLactivated islet gene expression showed that PRL could increase insulin mRNA in a glucose-independent manner, but when in combination, glucose and PRL acted synergistically to induce rat I promoter activity [180]. Insulin acts at the level of the pituitary to induce PRL gene transcription, which in turn activates insulin transcription, suggesting a possible mechanism for the regulation of carbohydrate metabolism during pregnancy.

Effects of GH (which also binds the PRL receptor) on beta cell proliferation and gene expression seem to involve different domains of the receptor. Activation of JAK2 directly phoshorylates the STAT1 and STAT3 proteins, which then bind and activate the cFos gene, hence promoting mitosis [175]. Thus GH and PRL seem to activate different signalling pathways affecting distinct functions in the beta cell.

\section{Conclusions}

This review presents the complexity of the regulation of insulin gene expression, which is in accordance with the principal role this hormone plays in the coordination of metabolic processes. A considerable body of evidence has shown that beta cell-specific expression of the insulin gene is ascertained by a unique combination of transcription factors, which synergistically activate transcription. This mechanism also allows the beta cell to differentially respond to external stimuli by regulating the transcriptional response through more than one pathway. It is becoming apparent that positive and negative cross-talk between the signalling pathways (via second messengers and protein kinases) converge on the insulin promoter by modulating the appropriate transcription factors involved. The homeodomain-containing transcription factor PDX-1 emerges as a key player whose activity is modulated by several external stimuli (glucose, GLP-1, insulin, palmitate), i.e. via the activation of the PI3-K and MAPK pathways, thereby regulating insulin gene transcription (Fig.2). A thorough understanding of the intracellular signalling events in response to external stimuli should clarify essential pathways for the normal functioning of beta cells. Ultimately, this will provide the basis for novel therapies for Type II diabetes.

Sources. The review is based on the relevant literature in the English language during the period 1967-2001. The sources available to the authors 
were integrated with sources identified through PubMed. The search was based on the following keywords: insulin, pancreas, islet, beta cells, transcription, VNTR, PDX-1/IPF-1, helix loop helix, homeobox, CRE, coactivators, glucose, glucocorticoid, GLP-1, FFAs, leptin, growth hormone, prolactin, STAT, kinases, glucotoxicity, diabetes.

Acknowledgements. The authors wish to express their gratitude to Michal Shoshkes and Tamara Gurewitz for their contributions. Our sincere thanks to Dr L. Havin and Dr C. L. Eisenberger for their valuable suggestions and for critically reading the manuscript. We would like to apologise to all the researchers whose work could not be cited due to space limitations. The authors have been supported by the Juvenile Foundation International (grant no. 1-2001-325), The Israel Academy of Sciences, and the European Community (BMH4-98-3448).

\section{References}

1. Chan SJ, Keim P, Steiner DF (1976) Cell-free synthesis of rat preproinsulins: characterization and partial amino acid sequence determination. Proc Natl Acad Sci USA 73: 1964-1968

2. Harper ME, Ullrich A, Saunders GF (1981) Localization of the human insulin gene to the distal end of the short arm of chromosome 11. Proc Natl Acad Sci USA 78: $4458-4460$

3. Soares MB, Schon E, Henderson A et al. (1985) RNA-mediated gene duplication: the rat preproinsulin I gene is a functional retroposon. Mol Cell Biol 5: 2090-2103

4. Davies PO, Poirier C, Deltour L, Montagutelli X (1994) Genetic reassignment of the insulin-1 (Ins1) gene to distal mouse chromosome 19. Genomics 21: 665-667

5. Duvillie B, Bucchini D, Tang T, Jami J, Paldi A (1998) Imprinting at the mouse Ins2 locus: evidence for cis- and trans-allelic interactions. Genomics 47: 52-57

6. Giddings SJ, Carnaghi LR (1988) The two nonallelic rat insulin mRNAs and pre-mRNAs are regulated coordinately in vivo. J Biol Chem 263: 3845-3849

7. Koranyi L, Permutt MA, Chirgwin JM, Giddings SJ (1989) Proinsulin I and II gene expression in inbred mouse strains. Mol Endocrinol 3: 1895-1902

8. Steiner DF, Chan SJ, Welsh JM, Kwok SC (1985) Structure and evolution of the insulin gene. Annu Rev Genet 19: 463-484

9. Gittes GK, Rutter WJ (1992) Onset of cell-specific gene expression in the developing mouse pancreas. Proc Natl Acad Sci USA 89: 1128-1132

10. Polak M, Bouchareb-Banaei L, Scharfmann R, Czernichow P (2000) Early pattern of differentiation in the human pancreas. Diabetes 49: 225-232

11. German M, Ashcroft S, Docherty K et al. (1995) The insulin gene promoter. A simplified nomenclature. Diabetes 44: 1002-1004

12. Hanahan D (1985) Heritable formation of pancreatic beta-cell tumours in transgenic mice expressing recombinant insulin/simian virus 40 oncogenes. Nature 315: 115-122

13. Bucchini D, Madsen O, Desbois P, Pictet R, Jami J (1989) $B$ islet cells of pancreas are the site of expression of the human insulin gene in transgenic mice. Exp Cell Res 180: $467-474$
14. Selden RF, Skoskiewicz MJ, Howie KB, Russell PS, Goodman HM (1986) Regulation of human insulin gene expression in transgenic mice. Nature 321: 525-528

15. Fromont-Racine M, Bucchini D, Madsen O et al. (1990) Effect of 5'-flanking sequence deletions on expression of the human insulin gene in transgenic mice. Mol Endocrinol 4: 669-677

16. Dandoy-Dron F, Monthioux E, Jami J, Bucchini D (1991) Regulatory regions of rat insulin I gene necessary for expression in transgenic mice. Nucleic Acids Res 19: 4925-4930

17. Karlsson O, Edlund T, Moss JB, Rutter WJ, Walker MD (1987) A mutational analysis of the insulin gene transcription control region: expression in beta cells is dependent on two related sequences within the enhancer. Proc Natl Acad Sci USA 84: 8819-8823

18. Crowe DT, Tsai MJ (1989) Mutagenesis of the rat insulin II 5'-flanking region defines sequences important for expression in HIT cells. Mol Cell Biol 9: 1784-1789

19. Whelan J, Poon D, Weil PA, Stein R (1989) Pancreatic beta-cell-type-specific expression of the rat insulin II gene is controlled by positive and negative cellular transcriptional elements. Mol Cell Biol 9: 3253-3259

20. Odagiri H, Wang J, German MS (1996) Function of the human insulin promoter in primary cultured islet cells. J Biol Chem 271: 1909-1915

21. Boam DS, Clark AR, Docherty K (1990) Positive and negative regulation of the human insulin gene by multiple trans-acting factors. J Biol Chem 265: 8285-8296

22. Massari ME, Murre C (2000) Helix-loop-helix proteins: regulators of transcription in eucaryotic organisms. Mol Cell Biol 20: 429-440

23. Naya FJ, Stellrecht CM, Tsai MJ (1995) Tissue-specific regulation of the insulin gene by a novel basic helix-loophelix transcription factor. Genes Dev 9: 1009-1019

24. Naya FJ, Huang HP, Qiu Y et al. (1997) Diabetes, defective pancreatic morphogenesis, and abnormal enteroendocrine differentiation in BETA2/neuroD-deficient mice. Genes Dev 11: 2323-2334

25. Malecki MT, Jhala US, Antonellis A et al. (1999) Mutations in NEUROD1 are associated with the development of type 2 diabetes mellitus. Nat Genet 23: 323-328

26. Itkin-Ansari P, Bain G, Beattie GM, Murre C, Hayek A, Levine F (1996) E2A gene products are not required for insulin gene expression. Endocrinology 137: 35403543

27. Dumonteil E, Laser B, Constant I, Philippe J (1998) Differential regulation of the glucagon and insulin I gene promoters by the basic helix-loop-helix transcription factors E47 and BETA2. J Biol Chem 273: 19945-19954

28. Read ML, Clark AR, Docherty K (1993) The helix-loophelix transcription factor USF (upstream stimulating factor) binds to a regulatory sequence of the human insulin gene enhancer. Biochem J 295: 233-237

29. Petersen HV, Serup P, Leonard J, Michelsen BK, Madsen OD (1994) Transcriptional regulation of the human insulin gene is dependent on the homeodomain protein STF1/IPF1 acting through the CT boxes. Proc Natl Acad Sci USA 91: 10465-10469

30. Marshak S, Totary H, Cerasi E, Melloul D (1996) Purification of the beta-cell glucose-sensitive factor that transactivates the insulin gene differentially in normal and transformed islet cells. Proc Natl Acad Sci USA 93: 15057-15062

31. German MS, Wang J (1994) The insulin gene contains multiple transcriptional elements that respond to glucose. Mol Cell Biol 14: 4067-4075 
32. Wright CV, Schnegelsberg P, De Robertis EM (1989) XlHbox 8: a novel Xenopus homeo protein restricted to a narrow band of endoderm. Development 105: 787-794

33. Ohlsson H, Karlsson K, Edlund T (1993) IPF1, a homeodomain-containing transactivator of the insulin gene. EMBO J 12: 4251-4259

34. Leonard J, Peers B, Johnson T, Ferreri K, Lee S, Montminy MR (1993) Characterization of somatostatin transactivating factor-1, a novel homeobox factor that stimulates somatostatin expression in pancreatic islet cells. Mol Endocrinol 7: 1275-1283

35. Miller CP, McGehee RE Jr, Habener JF (1994) IDX-1: a new homeodomain transcription factor expressed in rat pancreatic islets and duodenum that transactivates the somatostatin gene. EMBO J 13: 1145-1156

36. Melloul D, Ben-Neriah Y, Cerasi E (1993) Glucose modulates the binding of an islet-specific factor to a conserved sequence within the rat I and the human insulin promoters. Proc Natl Acad Sci USA 90: 3865-3869

37. MacFarlane WM, Read ML, Gilligan M, Bujalska I, Docherty K (1994) Glucose modulates the binding activity of the beta-cell transcription factor IUF1 in a phosphorylation-dependent manner. Biochem J 303: 625-631

38. Edlund H (2001) Developmental biology of the pancreas. Diabetes 50 [Suppl 1]: S5-S9

39. Peers B, Leonard J, Sharma S, Teitelman G, Montminy MR (1994) Insulin expression in pancreatic islet cells relies on cooperative interactions between the helix loop helix factor E47 and the homeobox factor STF-1. Mol Endocrinol 8: 1798-1806

40. Serup P, Petersen HV, Pedersen EE et al. (1995) The homeodomain protein IPF-1/STF-1 is expressed in a subset of islet cells and promotes rat insulin 1 gene expression dependent on an intact E1 helix-loop-helix factor binding site. Biochem J 310: 997-1003

41. Waeber G, Thompson N, Nicod P, Bonny C (1996) Transcriptional activation of the GLUT2 gene by the IPF-1/ STF-1/IDX-1 homeobox factor. Mol Endocrinol 10: 1327-1334

42. Watada H, Kajimoto Y, Umayahara Y et al. (1996) The human glucokinase gene beta-cell-type promoter: an essential role of insulin promoter factor 1/PDX-1 in its activation in HIT-T15 cells. Diabetes 45: 1478-1488

43. Carty MD, Lillquist JS, Peshavaria M, Stein R, Soeller WC (1997) Identification of cis- and trans-active factors regulating human islet amyloid polypeptide gene expression in pancreatic beta-cells. J Biol Chem 272: 11986-11993

44. Jonsson J, Carlsson L, Edlund T, Edlund H (1994) Insulinpromoter-factor 1 is required for pancreas development in mice. Nature 371: 606-609

45. Ahlgren U, Jonsson J, Jonsson L, Simu K, Edlund H (1998) Beta-cell-specific inactivation of the mouse Ipf1/ $\mathrm{Pd} \times 1$ gene results in loss of the beta-cell phenotype and maturity onset diabetes. Genes Dev 12: 1763-1768

46. Stoffers DA, Zinkin NT, Stanojevic V, Clarke WL, Habener JF (1997) Pancreatic agenesis attributable to a single nucleotide deletion in the human IPF1 gene coding sequence. Nat Genet 15: 106-110

47. Stoffers DA, Ferrer J, Clarke WL, Habener JF (1997) Early-onset type-II diabetes mellitus (MODY4) linked to IPF1. Nat Genet 17: 138-139

48. Peers B, Sharma S, Johnson T, Kamps M, Montminy M (1995) The pancreatic islet factor STF-1 binds cooperatively with $\mathrm{Pbx}$ to a regulatory element in the somatostatin promoter: importance of the FPWMK motif and of the homeodomain. Mol Cell Biol 15: 7091-7097
49. Swift GH, Liu Y, Rose SD et al. (1998) An endocrine-exocrine switch in the activity of the pancreatic homeodomain protein PDX1 through formation of a trimeric complex with PBX1b and MRG1 (MEIS2). Mol Cell Biol 18: 5109-5120

50. Dutta S, Gannon M, Peers B, Wright C, Bonner-Weir S, Montminy M (2001) PDX:PBX complexes are required for normal proliferation of pancreatic cells during development. Proc Natl Acad Sci USA 98: 1065-1070

51. Karlsson O, Thor S, Norberg T, Ohlsson H, Edlund T (1990) Insulin gene enhancer binding protein Isl-1 is a member of a novel class of proteins containing both a homeo- and a Cys-His domain. Nature 344: 879-882

52. German MS, Wang J, Chadwick RB, Rutter WJ (1992) Synergistic activation of the insulin gene by a LIM-homeo domain protein and a basic helix-loop-helix protein: building a functional insulin minienhancer complex. Genes Dev 6: 2165-2176

53. Emens LA, Landers DW, Moss LG (1992) Hepatocyte nuclear factor 1 alpha is expressed in a hamster insulinoma line and transactivates the rat insulin I gene. Proc Natl Acad Sci USA 89: 7300-7304

54. Ohneda K, Mirmira RG, Wang J, Johnson JD, German MS (2000) The homeodomain of PDX-1 mediates multiple protein-protein interactions in the formation of a transcriptional activation complex on the insulin promoter. Mol Cell Biol 20: 900-911

55. Tomonari A, Yoshimoto K, Mizusawa N, Iwahana H, Itakura M (1999) Differential regulation of the human insulin gene transcription by GG1 and GG2 elements with GG- and C1-binding factors. Biochim Biophys Acta 1446: 233-242

56. Stellrecht CM, DeMayo FJ, Finegold MJ, Tsai MJ (1997) Tissue-specific and developmental regulation of the rat insulin II gene enhancer, RIPE3, in transgenic mice. J Biol Chem 272: 3567-3572

57. Harrington RH, Sharma A (2001) Transcription factors recognizing overlapping $\mathrm{C} 1-\mathrm{A} 2$ binding sites positively regulate insulin gene expression. $J$ Biol Chem 276: 104-113

58. Shieh SY, Tsai MJ (1991) Cell-specific and ubiquitous factors are responsible for the enhancer activity of the rat insulin II gene. J Biol Chem 266: 16708-16714

59. Zhao L, Cissell MA, Henderson E, Colbran R, Stein R (2000) The RIPE3b1 activator of the insulin gene is composed of a protein(s) of approximately $43 \mathrm{kDa}$, whose DNA binding activity is inhibited by protein phosphatase treatment. J Biol Chem 275: 10532-10537

60. Matsuoka Ta T, Zhao L, Stein R (2001) The DNA-binding activity of insulin's RIPE3b1 transcription factor appears to be regulated by tyrosine phosphorylation. J Biol Chem 17: 17

61. Daniel PB, Walker WH, Habener JF (1998) Cyclic AMP signalling and gene regulation. Annu Rev Nutr 18: 353-383

62. Grill V, Cerasi E (1974) Stimulation by D-glucose of cyclic adenosine 3':5'-monophosphate accumulation and insulin release in isolated pancreatic islets of the rat. $\mathrm{J}$ Biol Chem 249: 4196-4201

63. Drucker DJ, Philippe J, Mojsov S, Chick WL, Habener JF (1987) Glucagon-like peptide I stimulates insulin gene expression and increases cyclic AMP levels in a rat islet cell line. Proc Natl Acad Sci USA 84: 3434-3438

64. Skoglund G, Hussain MA, Holz GG (2000) Glucagon-like peptide 1 stimulates insulin gene promoter activity by protein kinase A-independent activation of the rat insulin I gene cAMP response element. Diabetes 49: 1156-1164 
65. Philippe J, Missotten M (1990) Functional characterization of a cAMP-responsive element of the rat insulin I gene. J Biol Chem 265: 1465-1469

66. Buteau J, Roduit R, Susini S, Prentki M (1999) Glucagonlike peptide- 1 promotes DNA synthesis, activates phosphatidylinositol 3-kinase and increases transcription factor pancreatic and duodenal homeobox gene 1 (PDX-1) DNA binding activity in beta (INS-1)-cells. Diabetologia 42: 856-864

67. Nielsen DA, Welsh M, Casadaban MJ, Steiner DF (1985) Control of insulin gene expression in pancreatic beta-cells and in an insulin-producing cell line, RIN-5F cells. I. Effects of glucose and cyclic AMP on the transcription of insulin mRNA. J Biol Chem 260: 13585-13589

68. Hammonds P, Schofield PN, Ashcroft SJ (1987) Glucose regulates preproinsulin messenger RNA levels in a clonal cell line of simian virus 40-transformed B cells. FEBS Lett 213: 149-154

69. Inagaki N, Maekawa T, Sudo T, Ishii S, Seino Y, Imura H (1992) c-Jun represses the human insulin promoter activity that depends on multiple cAMP response elements. Proc Natl Acad Sci USA 89: 1045-1049

70. Oetjen E, Diedrich T, Eggers A, Eckert B, Knepel W (1994) Distinct properties of the cAMP-responsive element of the rat insulin I gene. J Biol Chem 269: 27036-27044

71. Inada A, Someya Y, Yamada Y et al. (1999) The cyclic AMP response element modulator family regulates the insulin gene transcription by interacting with transcription factor IID. J Biol Chem 274: 21095-21103

72. Inada A, Yamada Y, Someya Yet al. (1998) Transcriptional repressors are increased in pancreatic islets of type 2 diabetic rats. Biochem Biophys Res Commun 253: 712-718

73. Hussain MA, Daniel PB, Habener JF (2000) Glucagon stimulates expression of the inducible cAMP early repressor and suppresses insulin gene expression in pancreatic beta-cells. Diabetes 49: 1681-1690

74. Foulkes NS, Borrelli E, Sassone-Corsi P (1991) CREM gene: use of alternative DNA-binding domains generates multiple antagonists of cAMP-induced transcription. Cell 64: 739-749

75. Eggers A, Siemann G, Blume R, Knepel W (1998) Genespecific transcriptional activity of the insulin cAMP-responsive element is conferred by NF-Y in combination with cAMP response element-binding protein. J Biol Chem 273: 18499-18508

76. Read ML, Masson MR, Docherty K (1997) A RIPE3b1like factor binds to a novel site in the human insulin promoter in a redox-dependent manner. FEBS Lett 418: $68-72$

77. Sander M, Neubuser A, Kalamaras J, Ee HC, Martin GR, German MS (1997) Genetic analysis reveals that PAX6 is required for normal transcription of pancreatic hormone genes and islet development. Genes Dev 11: 1662-1673

78. Fujitani Y, Kajimoto Y, Yasuda T et al. (1999) Identification of a portable repression domain and an E1A-responsive activation domain in Pax4: a possible role of Pax4 as a transcriptional repressor in the pancreas. Mol Cell Biol 19: 8281-8291

79. Smith SB, Ee HC, Conners JR, German MS (1999) Paired-homeodomain transcription factor PAX4 acts as a transcriptional repressor in early pancreatic development. Mol Cell Biol 19: 8272-8280

80. Campbell SC, Cragg H, Elrick LJ, Macfarlane WM, Shennan KI, Docherty K (1999) Inhibitory effect of Pax4 on the human insulin and islet amyloid polypeptide (IAPP) promoters. FEBS Lett 463: 53-57
81. Dohrmann C, Gruss P, Lemaire L (2000) Pax genes and the differentiation of hormone-producing endocrine cells in the pancreas. Mech Dev 92: 47-54

82. Kennedy GC, Rutter WJ (1992) Pur-1, a zinc-finger protein that binds to purine-rich sequences, transactivates an insulin promoter in heterologous cells. Proc Natl Acad Sci USA 89: 11498-11502

83. Bennett ST, Todd JA (1996) Human type 1 diabetes and the insulin gene: principles of mapping polygenes. Annu Rev Genet 30: 343-370

84. Ong KK, Phillips DI, Fall C et al. (1999) The insulin gene VNTR, type 2 diabetes and birth weight. Nat Genet 21: 262-263

85. Owerbach D, Gabbay KH (1996) The search for IDDM susceptibility genes: the next generation. Diabetes 45: 544-551

86. Kennedy GC, German MS, Rutter WJ (1995) The minisatellite in the diabetes susceptibility locus IDDM 2 regulates insulin transcription. Nat Genet 9: 293-298

87. Bennett ST, Lucassen AM, Gough SC et al. (1995) Susceptibility to human type 1 diabetes at IDDM 2 is determined by tandem repeat variation at the insulin gene minisatellite locus. Nat Genet 9: 284-292

88. Lew A, Rutter WJ, Kennedy GC (2000) Unusual DNA structure of the diabetes susceptibility locus IDDM 2 and its effect on transcription by the insulin promoter factor Pur-1/MAZ. Proc Natl Acad Sci USA 97: 12508-12512

89. Hammond-Kosack MC, Dobrinski B, Lurz R, Docherty K, Kilpatrick MW (1992) The human insulin gene linked polymorphic region exhibits an altered DNA structure. Nucleic Acids Res 20: 231-236

90. Catasti P, Chen X, Moyzis RK, Bradbury EM, Gupta G (1996) Structure-function correlations of the insulinlinked polymorphic region. J Mol Biol 264: 534-545

91. Peshavaria M, Henderson E, Sharma A, Wright CV, Stein R (1997) Functional characterization of the transactivation properties of the PDX-1 homeodomain protein. Mol Cell Biol 17: 3987-3996

92. Glick E, Leshkowitz D, Walker MD (2000) Transcription factor BETA2 acts cooperatively with E2A and PDX1 to activate the insulin gene promoter. J Biol Chem 275: 2199-2204

93. Hwung YP, Gu YZ, Tsai MJ (1990) Cooperativity of sequence elements mediates tissue specificity of the rat insulin II gene. Mol Cell Biol 10: 1784-1788

94. Sharma A, Stein R (1994) Glucose-induced transcription of the insulin gene is mediated by factors required for beta-cell-type-specific expression. Mol Cell Biol 14: 871-879

95. Thomas MK, Yao KM, Tenser MS, Wong GG, Habener JF (1999) Bridge-1, a novel PDZ-domain coactivator of E2A-mediated regulation of insulin gene transcription. Mol Cell Biol 19: 8492-8504

96. Imhof A, Yang XJ, Ogryzko VV, Nakatani Y, Wolffe AP, Ge H (1997) Acetylation of general transcription factors by histone acetyltransferases. Curr Biol 7: 689-692

97. Stein RW, Whelan J (1989) Insulin gene enhancer activity is inhibited by adenovirus $5 \mathrm{E} 1 \mathrm{a}$ gene products. Mol Cell Biol 9: 4531-4534

98. Eckner R, Yao TP, Oldread E, Livingston DM (1996) Interaction and functional collaboration of p300/CBP and bHLH proteins in muscle and B-cell differentiation. Genes Dev 10: 2478-2490

99. Qiu Y, Sharma A, Stein R (1998) p300 mediates transcriptional stimulation by the basic helix-loop-helix activators of the insulin gene. Mol Cell Biol 18: 2957-2964 
100. Sharma A, Moore M, Marcora E et al. (1999) The NeuroD1/BETA2 sequences essential for insulin gene transcription colocalize with those necessary for neurogenesis and p300/CREB binding protein binding. Mol Cell Biol 19: 704-713

101. Asahara H, Dutta S, Kao HY, Evans RM, Montminy M (1999) Pbx-Hox heterodimers recruit coactivator-corepressor complexes in an isoform-specific manner. Mol Cell Biol 19: 8219-8225

102. Laimins L, Holmgren-Konig M, Khoury G (1986) Transcriptional "silencer" element in rat repetitive sequences associated with the rat insulin 1 gene locus. Proc Natl Acad Sci USA 83: 3151-3155

103. Cordle SR, Whelan J, Henderson E, Masuoka H, Weil PA, Stein R (1991) Insulin gene expression in nonexpressing cells appears to be regulated by multiple distinct negative-acting control elements. Mol Cell Biol 11: 2881-2886

104. Clark AR, Wilson ME, Leibiger I, Scott V, Docherty K (1995) A silencer and an adjacent positive element interact to modulate the activity of the human insulin promoter. Eur J Biochem 232: 627-632

105. Goodman PA, Medina-Martinez O, Fernandez-Mejia C (1996) Identification of the human insulin negative regulatory element as a negative glucocorticoid response element. Mol Cell Endocrinol 120: 139-146

106. Wice BM, Bernal-Mizrachi E, Permutt MA (2001) Glucose and other insulin secretagogues induce, rather than inhibit, expression of Id-1 and Id-3 in pancreatic islet beta cells. Diabetologia 44: 453-463

107. Cordle SR, Henderson E, Masuoka H, Weil PA, Stein R (1991) Pancreatic beta-cell-type-specific transcription of the insulin gene is mediated by basic helix-loop-helix DNA-binding proteins. Mol Cell Biol 11: 1734-1738

108. Peyton M, Stellrecht CM, Naya FJ, Huang HP, Samora PJ, Tsai MJ (1996) BETA3, a novel helix-loop-helix protein, can act as a negative regulator of BETA2 and MyoD-responsive genes. Mol Cell Biol 16: 626-633

109. Robinson GL, Henderson E, Massari ME, Murre C, Stein R (1995) c-jun inhibits insulin control element-mediated transcription by affecting the transactivation potential of the E2A gene products. Mol Cell Biol 15: 1398-1404

110. Lu M, Seufert J, Habener JF (1997) Pancreatic beta-cellspecific repression of insulin gene transcription by CCAAT/enhancer-binding protein beta. Inhibitory interactions with basic helix-loop-helix transcription factor E47. J Biol Chem 272: 28349-28359

111. Seufert J, Weir GC, Habener JF (1998) Differential expression of the insulin gene transcriptional repressor CCAAT/enhancer-binding protein beta and transactivator islet duodenum homeobox-1 in rat pancreatic beta cells during the development of diabetes mellitus. J Clin Invest 101: 2528-2539

112. Jarrett RJ, Keen H, Track N (1967) Glucose and RNA synthesis in mammalian islets of Langerhans. Nature 213: 634-635

113. Permutt MA, Kipnis DM (1972) Insulin biosynthesis. I. On the mechanism of glucose stimulation. J Biol Chem 247: 1194-1199

114. Docherty K, Clark AR (1994) Nutrient regulation of insulin gene expression. FASEB J 8: 20-27

115. Thorens B, Sarkar HK, Kaback HR, Lodish HF (1988) Cloning and functional expression in bacteria of a novel glucose transporter present in liver, intestine, kidney, and beta-pancreatic islet cells. Cell 55: 281-290

116. Matschinsky FM (1990) Glucokinase as glucose sensor and metabolic signal generator in pancreatic beta-cells and hepatocytes. Diabetes 39: 647-652
117. Goodison S, Kenna S, Ashcroft SJ (1992) Control of insulin gene expression by glucose. Biochem J 285: 563-568

118. Ferrer J, Gomis R, Fernandez Alvarez J, Casamitjana R, Vilardell E (1993) Signals derived from glucose metabolism are required for glucose regulation of pancreatic islet GLUT2 mRNA and protein. Diabetes 42: 1273-1280

119. German MS (1993) Glucose sensing in pancreatic islet beta cells: the key role of glucokinase and the glycolytic intermediates. Proc Natl Acad Sci USA 90: 1781-1785

120. German MS, Moss LG, Rutter WJ (1990) Regulation of insulin gene expression by glucose and calcium in transfected primary islet cultures. J Biol Chem 265: 22063-22066

121. Sharma A, Fusco-DeMane D, Henderson E, Efrat S, Stein R (1995) The role of the insulin control element and RIPE3b1 activators in glucose-stimulated transcription of the insulin gene. Mol Endocrinol 9: 1468-1476

122. Sander M, Griffen SC, Huang J, German MS (1998) A novel glucose-responsive element in the human insulin gene functions uniquely in primary cultured islets. Proc Natl Acad Sci USA 95: 11572-11577

123. Macfarlane WM, Shepherd RM, Cosgrove KE, James RF, Dunne MJ, Docherty K (2000) Glucose modulation of insulin mRNA levels is dependent on transcription factor PDX-1 and occurs independently of changes in intracellular $\mathrm{Ca}^{+}$. Diabetes 49: 418-423

124. Leibowitz G, Ferber S, Apelqvist A et al. (2001) IPF1/ PDX1 deficiency and beta-cell dysfunction in Psammomys obesus, an animal with type 2 diabetes. Diabetes 50: 1799-1806

125. Lu M, Miller C, Habener JF (1996) Functional regions of the homeodomain protein IDX-1 required for transactivation of the rat somatostatin gene. Endocrinology 137: 2959-2967

126. Shushan EB, Cerasi E, Melloul D (1999) Regulation of the insulin gene by glucose: stimulation of transactivation potency of human PDX-1 N-terminal domain. DNA Cell Biol 18: 471-479

127. Peshavaria M, Cissell MA, Henderson E, Petersen HV, Stein R (2000) The PDX-1 activation domain provides specific functions necessary for transcriptional stimulation in pancreatic beta-cells. Mol Endocrinol 14: 1907-1917

128. Petersen HV, Peshavaria M, Pedersen AA, Philippe J, Stein R, Madsen OD, Serup P (1998) Glucose stimulates the activation domain potential of the PDX-1 homeodomain transcription factor. FEBS Lett 431: 362-366

129. Efrat S, Surana M, Fleischer N (1991) Glucose induces insulin gene transcription in a murine pancreatic beta- cell line. J Biol Chem 266: 11141-11143

130. Leibiger IB, Leibiger B, Moede T, Berggren PO (1998) Exocytosis of insulin promotes insulin gene transcription via the insulin receptor/PI-3 kinase/p70 S6 kinase and CaM kinase pathways. Mol Cell 1: 933-938

131. de Vargas LM, Sobolewski J, Siegel R, Moss LG (1997) Individual beta cells within the intact islet differentially respond to glucose. J Biol Chem 272: 26573-26577

132. Kennedy HJ, Rafiq I, Pouli AE, Rutter GA (1999) Glucose enhances insulin promoter activity in MIN6 betacells independently of changes in intracellular $\mathrm{Ca}_{2}{ }^{+}$concentration and insulin secretion. Biochem J 342: 275-280

133. Jones PM, Persaud SJ (1998) Protein kinases, protein phosphorylation, and the regulation of insulin secretion from pancreatic beta-cells. Endocr Rev 19: 429-461

134. Macfarlane WM, Smith SB, James RF et al. (1997) The p38/reactivating kinase mitogen-activated protein kinase cascade mediates the activation of the transcription factor insulin upstream factor 1 and insulin gene transcription by 
high glucose in pancreatic beta-cells. J Biol Chem 272: 20936-20944

135. Macfarlane WM, McKinnon CM, Felton-Edkins ZA, Cragg H, James RF, Docherty K (1999) Glucose stimulates translocation of the homeodomain transcription factor PDX1 from the cytoplasm to the nucleus in pancreatic beta-cells. J Biol Chem 274: 1011-1016

136. Rafiq I, da Silva Xavier G, Hooper S, Rutter GA (2000) Glucose-stimulated preproinsulin gene expression and nuclear translocation of pancreatic duodenum homeobox-1 require activation of phosphatidylinositol 3-kinase but not p38 MAPK/SAPK2. J Biol Chem 275: 15977-15984

137. Sempoux C, Guiot Y, Dubois D, Moulin P, Rahier J (2001) Human type 2 diabetes: morphological evidence for abnormal beta-cell function. Diabetes 50 [Suppl 1]: S172-S177

138. Sharma A, Olson LK, Robertson RP, Stein R (1995) The reduction of insulin gene transcription in HIT-T15 beta cells chronically exposed to high glucose concentration is associated with the loss of RIPE3b1 and STF-1 transcription factor expression. Mol Endocrinol 9: 1127-1134

139. Poitout V, Olson LK, Robertson RP (1996) Chronic exposure of betaTC-6 cells to supraphysiologic concentrations of glucose decreases binding of the RIPE3b1 insulin gene transcription activator. J Clin Invest 97: 1041-1046

140. Marshak S, Leibowitz G, Bertuzzi F et al. (1999) Impaired beta-cell functions induced by chronic exposure of cultured human pancreatic islets to high glucose. Diabetes 48: $1230-1236$

141. Matsuoka T, Kajimoto Y, Watada H et al. (1997) Glycation-dependent, reactive oxygen species-mediated suppression of the insulin gene promoter activity in HIT cells. J Clin Invest 99: 144-150

142. Marshak S, Benshushan E, Shoshkes M, Havin L, Cerasi E, Melloul D (2000) Functional conservation of regulatory elements in the pdx-1 gene: PDX-1 and hepatocyte nuclear factor 3 beta transcription factors mediate beta-cellspecific expression. Mol Cell Biol 20: 7583-7590

143. Ben-Shushan E, Marshak S, Shoshkes M, Cerasi E, Melloul D (2001) A pancreatic beta-cell-specific enhancer in the human PDX-1 gene is regulated by hepatocyte nuclear factor 3beta (HNF-3beta), HNF-1alpha, and SPs transcription factors. J Biol Chem 276: 17533-17540

144. Gerrish K, Gannon M, Shih D et al. (2000) Pancreatic beta cell-specific transcription of the pdx-1 gene. The role of conserved upstream control regions and their hepatic nuclear factor 3beta sites. J Biol Chem 275: 3485-3492

145. Sharma S, Jhala US, Johnson T, Ferreri K, Leonard J, Montminy M (1997) Hormonal regulation of an islet-specific enhancer in the pancreatic homeobox gene STF-1. Mol Cell Biol 17: 2598-2604

146. Stoffers DA, Stanojevic V, Habener JF (1998) Insulin promoter factor-1 gene mutation linked to early-onset type 2 diabetes mellitus directs expression of a dominant negative isoprotein. J Clin Invest 102: 232-241

147. Macfarlane WM, Frayling TM, Ellard S et al. (1999) Missense mutations in the insulin promoter factor-1 gene predispose to type 2 diabetes. J Clin Invest 104: R33-R39

148. Argoud GM, Schade DS, Eaton RP (1987) Insulin suppresses its own secretion in vivo. Diabetes 36: 959-962

149. Ammon HP, Reiber C, Verspohl EJ (1991) Indirect evidence for short-loop negative feedback of insulin secretion in the rat. J Endocrinol 128: 27-34

150. Koranyi L, James DE, Kraegen EW, Permutt MA (1992) Feedback inhibition of insulin gene expression by insulin. J Clin Invest 89: 432-436
151. Rutter GA (1999) Insulin secretion: feed-forward control of insulin biosynthesis? Curr Biol 9: R443-R445

152. Withers DJ, Gutierrez JS, Towery H et al. (1998) Disruption of IRS- 2 causes type 2 diabetes in mice. Nature 391: 900-904

153. Kulkarni RN, Bruning JC, Winnay JN, Postic C, Magnuson MA, Kahn CR (1999) Tissue-specific knockout of the insulin receptor in pancreatic beta cells creates an insulin secretory defect similar to that in type 2 diabetes. Cell 96: 329-339

154. Leibiger B, Leibiger IB, Moede T et al. (2001) Selective insulin signalling through $\mathrm{A}$ and $\mathrm{B}$ insulin receptors regulates transcription of insulin and glucokinase genes in pancreatic beta cells. Mol Cell 7: 559-570

155. Xu GG, Gao ZY, Borge PD Jr, Jegier PA, Young RA, Wolf BA (2000) Insulin regulation of beta-cell function involves a feedback loop on SERCA gene expression, $\mathrm{Ca}^{+}$ homeostasis, and insulin expression and secretion. Biochemistry 39: 14912-14919

156. Wu H, MacFarlane WM, Tadayyon M, Arch JR, James RF, Docherty K (1999) Insulin stimulates pancreaticduodenal homoeobox factor-1 (PDX1) DNA- binding activity and insulin promoter activity in pancreatic beta cells. Biochem J 344 3: 813-818

157. Leibiger B, Wahlander K, Berggren PO, Leibiger IB (2000) Glucose-stimulated insulin biosynthesis depends on insulin-stimulated insulin gene transcription. J Biol Chem 275: 30153-30156

158. Grill V, Qvigstad E (2000) Fatty acids and insulin secretion. Br J Nutr 83 [Suppl 1]: S79-S84

159. Jacqueminet S, Briaud I, Rouault C, Reach G, Poitout V (2000) Inhibition of insulin gene expression by long-term exposure of pancreatic beta cells to palmitate is dependent on the presence of a stimulatory glucose concentration. Metabolism 49: 532-536

160. Ritz-Laser B, Meda P, Constant I et al. (1999) Glucose-induced preproinsulin gene expression is inhibited by the free fatty acid palmitate. Endocrinology 140: 4005-4014

161. Gremlich S, Bonny C, Waeber G, Thorens B (1997) Fatty acids decrease IDX-1 expression in rat pancreatic islets and reduce GLUT2, glucokinase, insulin, and somatostatin levels. J Biol Chem 272: 30261-30269

162. Briaud I, Harmon JS, Kelpe CL, Segu VB, Poitout V (2001) Lipotoxicity of the pancreatic beta-cell is associated with glucose-dependent esterification of fatty acids into neutral lipids. Diabetes 50: 315-321

163. Holz GG, Leech CA (2001) Glucagon-like peptide-1: An insulinotropic hormone with potent growth factor actions at the pancreatic islets of Langerhans. In: Habener JF, Hussain MA (eds) Molecular Basis of Pancreas Development and Function. Kluwer Acad Pub, Norwel, pp 109-141

164. Fehmann HC, Habener JF (1992) Galanin inhibits proinsulin gene expression stimulated by the insulinotropic hormone glucagon-like peptide-I(7-37) in mouse insulinoma beta TC-1 cells. Endocrinology 130: 2890-2896

165. Wang Y, Egan JM, Raygada M, Nadiv O, Roth J, Montrose-Rafizadeh C (1995) Glucagon-like peptide-1 affects gene transcription and messenger ribonucleic acid stability of components of the insulin secretory system in RIN 1046-38 cells. Endocrinology 136: 4910-4917

166. Hussain MA, Habener JF (2000) Glucagon-like peptide 1 increases glucose-dependent activity of the homeoprotein IDX-1 transactivating domain in pancreatic beta-cells. Biochem Biophys Res Commun 274: 616-619

167. Wang X, Cahill CM, Pineyro MA, Zhou J, Doyle ME, Egan JM (1999) Glucagon-like peptide-1 regulates the 
beta cell transcription factor, PDX-1, in insulinoma cells. Endocrinology 140: 4904-4907

168. Galsgaard ED, Gouilleux F, Groner B, Serup P, Nielsen JH, Billestrup N (1996) Identification of a growth hormone-responsive STAT5-binding element in the rat insulin 1 gene. Mol Endocrinol 10: 652-660

169. Kieffer TJ, Habener JF (2000) The adipoinsular axis: effects of leptin on pancreatic beta-cells. Am J Physiol Endocrinol Metab 278: E1-E14

170. Zhao AZ, Bornfeldt KE, Beavo JA (1998) Leptin inhibits insulin secretion by activation of phosphodiesterase $3 \mathrm{~B}$. J Clin Invest 102: 869-873

171. Seufert J, Kieffer TJ, Habener JF (1999) Leptin inhibits insulin gene transcription and reverses hyperinsulinemia in leptin-deficient ob/ob mice. Proc Natl Acad Sci USA 96: 674-679

172. Shimizu H, Ohtani K, Tsuchiya Tet al. (1997) Leptin stimulates insulin secretion and synthesis in HIT-T 15 cells. Peptides 18: 1263-1266

173. Roduit R, Thorens B (1997) Inhibition of glucose-induced insulin secretion by long-term preexposure of pancreatic islets to leptin. FEBS Lett 415: 179-182

174. Morton NM, Emilsson V, de Groot P, Pallett AL, Cawthorne MA (1999) Leptin signalling in pancreatic islets and clonal insulin-secreting cells. J Mol Endocrinol 22: 173-184
175. Nielsen JH, Galsgaard ED, Moldrup A et al. (2001) Regulation of beta-cell mass by hormones and growth factors. Diabetes 50 [Suppl 1]: S25-S29

176. Herrington J, Smit LS, Schwartz J, Carter-Su C (2000) The role of STAT proteins in growth hormone signalling. Oncogene 19: 2585-2597

177. Galsgaard ED, Nielsen JH, Moldrup A (1999) Regulation of prolactin receptor (PRLR) gene expression in insulinproducing cells. Prolactin and growth hormone activate one of the rat prlr gene promoters via STAT5 a and STAT5 b. J Biol Chem 274: 18686-18692

178. Stout LE, Svensson AM, Sorenson RL (1997) Prolactin regulation of islet-derived INS-1 cells: characteristics and immunocytochemical analysis of STAT5 translocation. Endocrinology 138: 1592-1603

179. Billestrup N, Bouchelouche P, Allevato G, Ilondo M, Nielsen JH (1995) Growth hormone receptor C-terminal domains required for growth hormone-induced intracellular free $\mathrm{Ca}^{+}$oscillations and gene transcription. Proc Natl Acad Sci USA 92: 2725-2729

180. Petryk A, Fleenor D, Driscoll P, Freemark M (2000) Prolactin induction of insulin gene expression: the roles of glucose and glucose transporter-2. J Endocrinol 164: 277-286 